BIS

Working paper No. 37

\title{
DOES THE TERM STRUCTURE PREDICT RECESSIONS? THE INTERNATIONAL EVIDENCE
}

by

Henri Bernard and Stefan Gerlach

September 1996

BANK FOR INTERNATIONAL SETTLEMENTS

Monetary and Economic Department

BASLE 
BIS Working Papers are written by members of the Monetary and Economic Department of the Bank for International Settlements and published by the Bank. The papers are on subjects of topical interest and are technical in character. The views expressed in them are those of their authors and not necessarily the views of the BIS.

(C) Bank for International Settlements 1996 CH-4002 Basle, Switzerland

All rights reserved. Brief excerpts may be reproduced or translated provided the source is stated.

ISSN 1020-0959 


\title{
DOES THE TERM STRUCTURE PREDICT RECESSIONS? THE INTERNATIONAL EVIDENCE
}

by

\author{
Henri Bernard and Stefan Gerlach
}

September 1996

\section{Abstract}

Following Estrella and Hardouvelis (1991) and Estrella and Mishkin (1995a, b), we study the ability of the term structure to predict recessions in eight countries. The results are fourfold. First, the yield curve provides information about the likelihood of future recessions in all countries. Second, term spreads are useful for predicting recessions as much as two years ahead. Third, while German and US spreads are frequently significant in the regressions for the other countries, the added information is limited except in Japan and the United Kingdom. Fourth, while leading indicators contain information beyond that in term spreads, this information is only useful for forecasting recessions in the immediate future. These findings provide further evidence of the potential usefulness of term spreads as indicators for monetary policy purposes. 



\section{Contents}

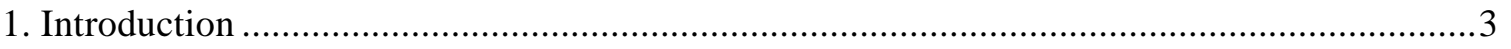

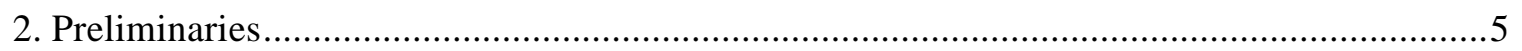

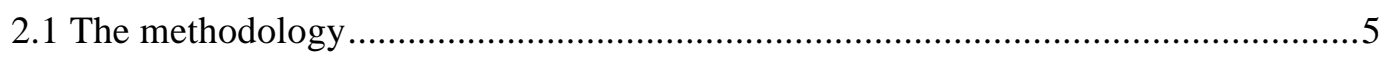

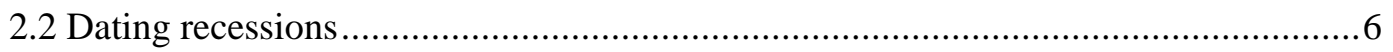

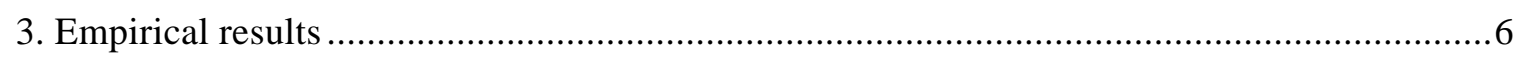

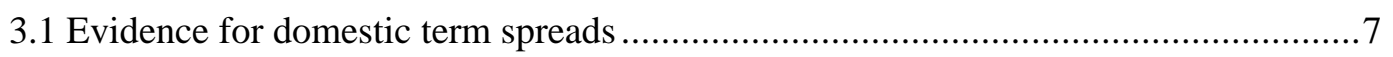

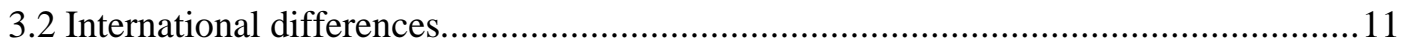

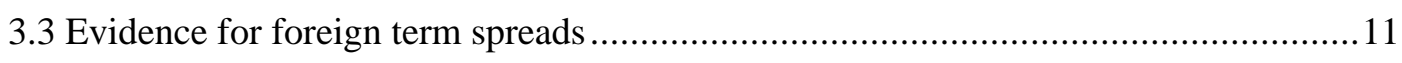

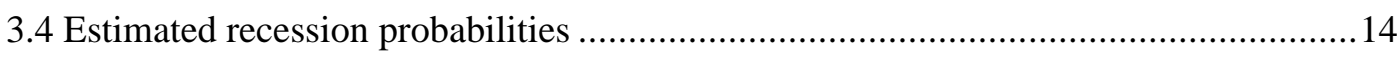

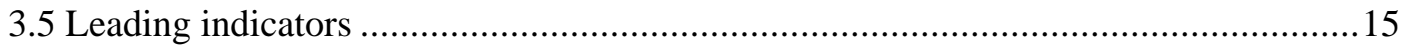

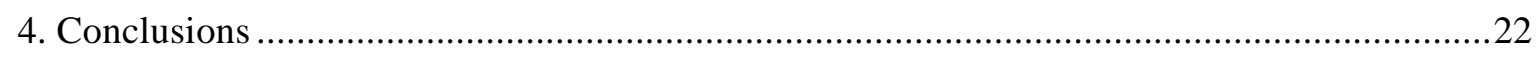

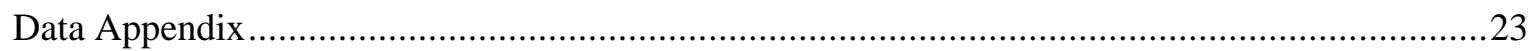

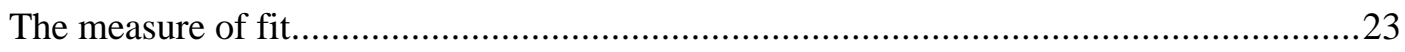

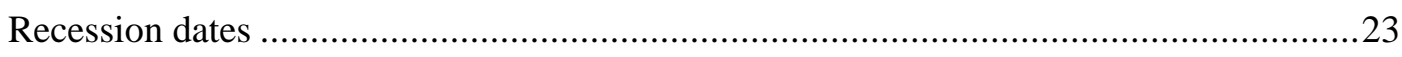

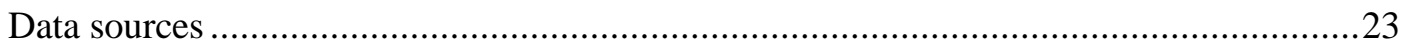

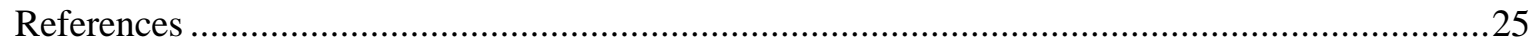





\section{Introduction}

Central banks have in the recent past been paying increasing attention to the term structure of interest rates as an indicator for monetary policy purposes. One reason for this is the fact that several authors have shown that the slope of the yield curve contains signficant information about the future path of macroeconomic variables in a number of countries. For instance, Fama (1990) and Mishkin (1990) show that spreads between long and short-term interest rates ("term spreads") contain information about future inflation in the United States. Jorion and Mishkin (1991) show that term spreads also contain information about inflation in the United States, Germany, Switzerland and, to a lesser extent, the United Kingdom. ${ }^{1}$ It thus appears that the usefulness of term spreads as indicators of inflation is not limited to the United States.

A number of authors have demonstrated that the term structure of interest rates also contains information about the future path of real economic activity. Bernanke (1990) and Estrella and Hardouvelis (1991) show that term spreads are useful for predicting future real economic growth in the United States. Plosser and Rouwenhorst (1994) present evidence that term spreads are useful for predicting real economic growth in the United States, Canada and Germany, but not in France and the United Kingdom. Furthermore, using data for the United States, Germany and the United Kingdom, they show that foreign term spreads are helpful for predicting future real economic growth in the domestic economy. ${ }^{2}$

The value of term spreads as an indicator of the likelihood of whether a recession, as defined by the NBER, will occur in the near future is forcefully demonstrated by Estrella and Hardouvelis (1991). Estrella and Mishkin (1995a) provide further evidence that term spreads forecast recessions in the United States as much as eight quarters in advance. They also show that term spreads dominate many other macroeconomic time series, in particular leading indicators, as predictors of real economic conditions. Estrella and Mishkin (1995b) study the ability of the term structure to predict recessions in France, Germany, Italy, the United Kingdom and the United States. ${ }^{3}$ The authors find that the term structure predicts recessions quite well in the United States and Germany, and to a lesser degree in the United Kingdom and Italy. In France, however, the term structure does not seem to contain information useful for predicting recessions. The authors also demonstrate that leading indicators do not contain any information in addition to that in the term spread about the likelihood of recessions.

The finding that the term spread is useful for predicting future macroeconomic conditions suggests that it is a good candidate for use as a monetary policy indicator. Three considerations make

Using a longer sample period and data for more maturities than Mishkin and Jorion (1991), Gerlach (1995) also shows that the term structure contains useful information about the future path of inflation in Germany.

2 See also Chen (1991), Hu (1993) and Bomhoff (1994, Ch.6) among others for a discussion of the information content of the term structure.

3 The paper by Estrella and Mishkin (1995b) considers a number of other issues concerning the term structure of interest rates and its use in the conduct of monetary policy, including whether central banks can control the slope of the term structure and how well the term structure forecasts inflation and several measures of real economic activity. 
it particularly attractive for this purpose. First, data on the term spreads are instantaneously available. This is helpful when attempting to predict the macroeconomic consequences of a large and discrete change in economic conditions, such as a devaluation or a new fiscal programme. Second, yield curve data are never revised. The problem of predicting future macroeconomic conditions on the basis of preliminary data that are likely to be revised to an unknown extent is therefore avoided. Third, since interest data are available for long maturities, it is possible to compute forecasts also for long time horizons. This is helpful since standard macroeconomic forecasts are typically limited to the following year or two.

In this paper we try to provide more cross-country evidence on the usefulness of term spreads in predicting the probability of a recession within the following eight quarters, using quarterly data for eight countries - Belgium, Canada, France, Germany, Japan, the Netherlands, the United Kingdom and the United States - spanning 1972:1-1993:4 (1977:1-1993:4 for Belgium and the Netherlands). In comparing the ability of term spreads to predict recession across countries, it is essential that the criteria used to define recessions do not vary between countries, since otherwise differences in the predictive ability may simply be due to differing definitions. To avoid this potentially serious problem, in this paper we use the recession chronology in Artis et al. (1995), who date recessions in twelve countries, starting in the early 1960s, using the same criteria.

The paper is organised as follows. In Section 2 we review the methodology and the data on recessions. Section 3 presents the empirical evidence. We first consider the information contained in the domestic spreads. While the results vary between countries, in all countries spreads do contain information about the probability of recessions in the future. The predictive ability is found to be highest in Germany, followed by the United States and Canada, and lowest in Japan. We find, as noted by Estrella and Mishkin (1995a) for the United States, that in many countries term spreads are useful for predicting recessions as much as six to eight quarters ahead. Since economic activity and the term structure are correlated across countries, foreign spreads may contain information about the probability of a recession in the domestic economy. We explore this hypothesis, but find that foreign spreads, while significant, seem to add little information useful for predicting future recessions in the domestic economy. Exceptions to this are Japan (for which the German spread adds information) and the United Kingdom (for which the spreads in the United States add information). Having demonstrated that the spread is useful in predicting future recessions, we review how the estimated recession probabilities evolve over time. Focusing on the ability of the spread to predict recession four quarters ahead, we show that the estimated recession probabilities have tended to shift considerably in advance of the onset recessions. Finally, since it is well-known that the information embodied in leading indicators is useful in predicting recessions, we end the empirical part by studying whether our findings regarding the usefulness of term spreads in predicting future recessions are modified if we also include a leading indicator in the probit regressions. While it is clear that the leading indicators do add information, they appear useful only in predicting recession in the subsequent one to three quarters. There is no evidence that leading indicators contain information for longer forecast 
horizons, for which term spreads continue to contain information. Section 4 summarises our conclusions.

It should be noted that we do not address the question why there is a relationship between the slope of the term structure and real economic growth. There are two competing hypotheses. The first of these holds that the relationship stems from the effects of monetary policy. To see this, assume that the central bank tightens monetary policy by raising short-term interest rates. Since monetary contractions are temporary, agents raise their expectations of future short-term rates by less than the change in the current short rate. Consequently, long interest rates also rise by less than the current short rate, leading to a downward-sloping term structure. Since monetary policy affects output with a lag of one to two years, the argument continues, the tightening of policy is associated with a reduction of future growth and an increased probability of a recession.

The alternative hypothesis is that the relationship between the term structure and output reflects the expectations of financial market participants regarding future economic growth. Suppose that anticipations of a recession start to take hold. Since inflation rates tend to fall in a period of low real growth, such expectations are likely to lead to a fall in long interest rates and a downward-sloping term structure. If expectations are correct on average, downward-sloping term structures are likely to be associated with future recessions.

Since the first hypothesis views the association between the slope of the term structure and recessions as arising from policy-induced changes in short interest rates, while the second hypothesis emphasises changes in long interest rates, one would expect it to be straightforward to discriminate between them. However, as is clear from the expectations hypothesis of the term structure, interest rates of different maturities are closely related. It is therefore difficult to distinguish econometrically between the two hypotheses. In this paper we therefore focus on establishing further evidence of the ability of the term structure to predict future recessions.

\section{Preliminaries}

\subsection{The methodology}

Following Estrella and Hardouvelis (1991) and Estrella and Mishkin (1995a,b), the results presented below stem from estimates of standard probit models. ${ }^{4}$ The need for the probit techniques arises from the fact that the dependent variable is a dummy variable that takes the value 1 if a recession occurred and 0 otherwise. The predicted values of the regression thus need to be constrained also to fall in the $0-1$ interval. This is done by choosing a non-linear functional relationship between the dependent and independent variables.

The probit regressions we estimate take the form

$$
P_{t}=F\left(\alpha+\beta \times S P R E A D_{t-k}\right)
$$

\footnotetext{
4 Pindyck and Rubinfeld (1991) contains an introduction to probit models.
} 
where $P_{t}$ is the dummy variable for recessions, $F$ is the cumulative normal function, and SPREAD is the long minus the short interest rate. ${ }^{5}$ The fitted values, $\hat{P}_{t}$, can be interpreted as the probability that a recession will occur, conditional on the observed value of the spread. The integer $k$ measures the time lag: for the spreads to be a useful indicator for monetary policy purposes they need to predict recessions in the future, that is, for $k>0$. By estimating the model on quarterly data for $k=0, \ldots, 8$ we can study the spread's ability to predict recessions up to two years ahead.

\subsection{Dating recessions}

Since the purpose of the paper is to provide some comparative evidence on the information implicit in the term structure, it is essential that the criteria used to define a recession do not vary between countries. To see why, suppose that two economies undergo exactly the same fluctuations in economic activity and that the term spreads have exactly the same predictive power in the two countries. Suppose, however, that the criteria used to define a recession are more lenient in one country, so that a larger fraction of the data points are classified as being in recession in the country in question. One would not then expect the econometric results to be comparable.

In order to mitigate this problem, we use recession dates proposed by Artis et al. (1995). ${ }^{6}$ These dates are obtained by employing a methodology which is based on that of the NBER, but which uses data for only one time series (industrial production). Despite this difference, Artis et al. (1995) show that their turning-point dates are very similar to the traditional NBER dates for the United States. The authors also claim that they found it easy to date business cycles in the other countries except possibly France, Belgium and the Netherlands - with their algorithm. It should be noted that the reliability of the results of this study hinges critically on the quality of the recession dates we use.

\section{Empirical results}

In this section we present the results. Several questions are of interest. First, how does the predictive ability of the spreads vary with the forecasting horizon? As stressed by Estrella and Mishkin (1995a), one reason why spreads are useful indicators for monetary policy purposes in the United States is that they tend to give ample warning. This raises the question of whether they also provide as much forewarning in other countries. ${ }^{7}$ Second, how useful are foreign spreads in predicting domestic recessions? Since movements in both term spreads and economic activity tend to be correlated across countries, one would expect the use also of foreign interest rates to permit sharper predictions about future recessions, as suggested by the empirical work of Plosser and Rouwenhorst (1994). This may be particularly useful for countries operating under fixed exchange rates, where

5 See the Data Appendix for more information about the interest rates used.

6 Artis et al. also provide business cycle dates for Italy, Spain, Ireland and Luxembourg. Since we were unable to find data on long interest rates going back to the mid-1970s for these countries, we excluded them from this study.

7 Estrella and Mishkin (1995b) state that the four quarter horizon was the "most successful" for the countries they considered, but do not provide results for other horizons. 
speculative pressures in the foreign exchange market can generate large swings in term spreads. Since the foreign exchange pressures tend to be temporary, such swings need not be associated with future recessions. It may also be useful for countries in which financial markets were deregulated only recently, for which data from the regulated period are not necessarily informative about financial market participants' expectations regarding future economic conditions. Third, are term spreads more informative than leading indicators about the likelihood of a recession? While Estrella and Mishkin (1995a) demonstrate that this is the case in the United States, this issue has not yet been addressed for the countries we study.

\subsection{Evidence for domestic term spreads}

Table 1 provides the results for estimating equation (1) using solely the domestic term spread as a regressor. The sample period is 1972:1-1993:4, except for Belgium and the Netherlands, for which it is 1977:1-1993:4. ${ }^{8}$ We let the forecast horizon, indexed by $k$, vary from zero to eight quarters: the interest rate data thus start as early as two years before the estimation period. Following Estrella and Mishkin (1995), we tabulate the t-statistics on the slope variable, the pseudo $\mathrm{R}^{2}$ and the $\log$ likelihood. ${ }^{9}$ Four aspects of the results are noteworthy.

First, while the results vary, in all countries the spreads are useful for predicting future recessions. Thus, the slope of the term structure is likely to be a useful indicator of future real economic activity for monetary policy purposes. Second, as judged by the significance of the slope parameter, the spread is able to predict recessions for $k \mathrm{~s}$ ranging from $0(k=1$ in the Netherlands and the United Kingdom) to $k=7$ in the Netherlands, the United Kingdom and the United States, and $k=8$ in Germany. ${ }^{10}$ These lead times are sufficiently long to be meaningful from a monetary policy perspective. Third, Graph 1 illustrates that the explanatory power, as measured by the pseudo $\mathrm{R}^{2}$, varies with the forecast horizon, $k$, and is "hump-shaped": the explanatory power rises from $k=0$, peaks after two to five quarters, and then falls gradually as increasingly higher $k \mathrm{~s}$ are considered. Since interest rates are forward-looking variables, it is not surprising that the pseudo $\mathrm{R}^{2} \mathrm{~s}$ initially rise. Fourth, the graph also illustrates that there are large differences between countries in the predictive power of the spread. The predictive power, as measured by the pseudo $\mathrm{R}^{2}$, is highest in Germany, followed by Canada and the United States, and lowest in Japan. One interesting question, to which we return below, is what factors can explain these differences.

The finding that the spreads are useful in predicting future recessions leads to the question of how the estimated recession probabilities depend on the spread. To address this issue we calculated the probability of a recession as a function of the current spread (see Table 2). Since the results indicate that the spreads are able to forecast recessions roughly equally well for $k=2,3$ and 4 ,

8 While both the interest rate and recession data are available monthly, we follow Estrella and Mishkin (1995a,b) and estimate the regression using quarterly data to permit comparison with their results.

9

The pseudo $\mathrm{R}^{2}$ was first proposed by Estrella (1995). It is also described in the Data Appendix.

10 This is also the case in Canada. However, the sign on the parameter is positive (rather than negative), suggesting that the correlation may be spurious. 
we focus on the case $k=4$, which is probably the most interesting from a monetary policy perspective.

Table 1

Pseudo $\mathbf{R}^{2}$ and t-statistics for probit models using domestic spread

Sample period: 1972:1-1993:4

\begin{tabular}{|c|c|c|c|c|c|c|c|c|c|}
\hline \multirow[b]{3}{*}{ Belgium $^{1} \ldots \ldots}$. & \multicolumn{9}{|c|}{ Number of quarters ahead $(k)$} \\
\hline & 0 & 1 & 2 & 3 & 4 & 5 & 6 & 7 & 8 \\
\hline & & & & & & & & & \\
\hline Pseudo $\mathrm{R}^{2}$ & 0.044 & 0.114 & 0.193 & 0.179 & 0.106 & 0.049 & 0.064 & 0.132 & 0.144 \\
\hline Domestic spread $^{2}$ & $-1.7^{*}$ & $-2.7 * * * *$ & $-3.3 * * *$ & $-3.2 * * *$ & $-2.6 * * *$ & -1.1 & 0.0 & 1.4 & 1.4 \\
\hline Log likelihood & -42.6 & -40.2 & -37.4 & -37.9 & -40.5 & -42.5 & -42.0 & -39.8 & -39.4 \\
\hline Canada .......... & & & & & & & & & \\
\hline Pseudo $\mathrm{R}^{2}$ & 0.395 & 0.578 & 0.500 & 0.287 & 0.175 & 0.069 & 0.006 & 0.009 & 0.006 \\
\hline Domestic spread $^{2}$ & $-5.1 * * *$ & $-5.4 * * * *$ & $-5.2 * * *$ & $-4.6 * * *$ & $-3.7 * * *$ & $-2.4 * *$ & -0.7 & 0.9 & $2.2 * *$ \\
\hline Log likelihood & -32.6 & -23.9 & -27.6 & -37.7 & -42.8 & -47.5 & -50.2 & -50.2 & -47.9 \\
\hline France ........... & & & & & & & & & \\
\hline Pseudo $\mathrm{R}^{2}$ & 0.034 & 0.106 & 0.355 & 0.298 & 0.172 & 0.048 & 0.006 & 0.003 & 0.015 \\
\hline Domestic spread $^{2}$ & $-1.7 *$ & -3.0 *** & $-4.6 * * *$ & $-4.4 * * *$ & $-3.6 * * *$ & $-2.0 * *$ & -0.7 & -0.5 & 1.1 \\
\hline Log likelihood & -51.0 & -47.8 & -36.4 & -39.0 & -44.8 & -50.4 & -52.3 & -52.4 & -51.9 \\
\hline Germany ........ & & & & & & & & & \\
\hline Pseudo $\mathrm{R}^{2}$ & 0.375 & 0.598 & 0.722 & 0.688 & 0.544 & 0.401 & 0.262 & 0.141 & 0.049 \\
\hline Domestic spread $^{2}$ & $-5.3^{* * * *}$ & $-5.7 * * *$ & $-5.3^{* * * * 1}$ & $-5.4 * * *$ & $-5.4 * * *$ & $-5.0 * * *$ & $-4.4 * * *$ & $-3.4^{* * * *}$ & $-2.1 * *$ \\
\hline Log likelihood & -40.3 & -28.8 & -21.7 & -23.7 & -31.7 & -39.1 & -45.8 & -51.4 & -55.5 \\
\hline Japan & & & & & & & & & \\
\hline Pseudo $\mathrm{R}^{2}$ & 0.047 & 0.064 & 0.062 & 0.035 & 0.006 & 0.001 & 0.001 & 0.001 & 0.001 \\
\hline Domestic spread $^{2}$ & $-1.9 *$ & $-2.2 * *$ & $-2.2 * *$ & $-1.7 *$ & -0.7 & -0.3 & -0.3 & -0.3 & 0.3 \\
\hline Log likelihood & -48.5 & -47.7 & -47.8 & -49.0 & -50.3 & -50.5 & -50.5 & -50.5 & -50.5 \\
\hline Netherlands 1 & & & & & & & & & \\
\hline Pseudo $\mathrm{R}^{2}$ & 0.001 & 0.053 & 0.125 & 0.126 & 0.114 & 0.209 & 0.142 & 0.080 & 0.033 \\
\hline Domestic spread $^{2}$ & -0.2 & $-1.9^{*}$ & $-2.8 * * *$ & $-2.8 * * *$ & $-2.7 * * *$ & $-3.5^{* * * *}$ & -3.0 **** & $-2.3^{* *}$ & -1.5 \\
\hline Log likelihood & -47.1 & -45.3 & -42.8 & -42.8 & -43.2 & -39.8 & -42.2 & -44.4 & -46.0 \\
\hline UK ................ & & & & & & & & & \\
\hline Pseudo $\mathrm{R}^{2}$ & 0.009 & 0.035 & 0.111 & 0.147 & 0.169 & 0.135 & 0.102 & 0.048 & 0.010 \\
\hline Domestic spread $^{2}$ & -0.9 & $-1.7 *$ & $-3.0 * * *$ & $-3.4 * * *$ & $-3.6^{* * *}$ & $-3.3^{* * * *}$ & $-2.9 * * *$ & $-2.0 * *$ & -0.9 \\
\hline Log likelihood & -54.6 & -53.5 & -50.1 & -48.5 & -47.5 & -49.0 & -50.5 & -52.9 & -54.6 \\
\hline US $\ldots \ldots \ldots \ldots \ldots$ & & & & & & & & & \\
\hline Pseudo $\mathrm{R}^{2}$ & 0.065 & 0.234 & 0.319 & 0.367 & 0.279 & 0.192 & 0.128 & 0.044 & 0.010 \\
\hline Domestic spread $^{2}$ & $-2.4 * *$ & $-4.3 * * *$ & $-4.9 * * *$ & $-5.1 * * *$ & $-4.6^{* * * *}$ & -3.9 ***, & $-3.2 * * *$ & $-1.9^{*}$ & -0.9 \\
\hline Log likelihood & -46.6 & -39.1 & -35.2 & -32.9 & -37.0 & -40.9 & -43.8 & -47.5 & -49.0 \\
\hline
\end{tabular}

${ }^{1}$ Sample period: 1977:1-1993:4.

2 t-statistics; *,** and *** denote significance at the $10 \%, 5 \%$ and $1 \%$ level respectively. 
Graph 1

Pseudo $\mathbf{R}^{2}$ as a function of forecast horizon: domestic and foreign spreads
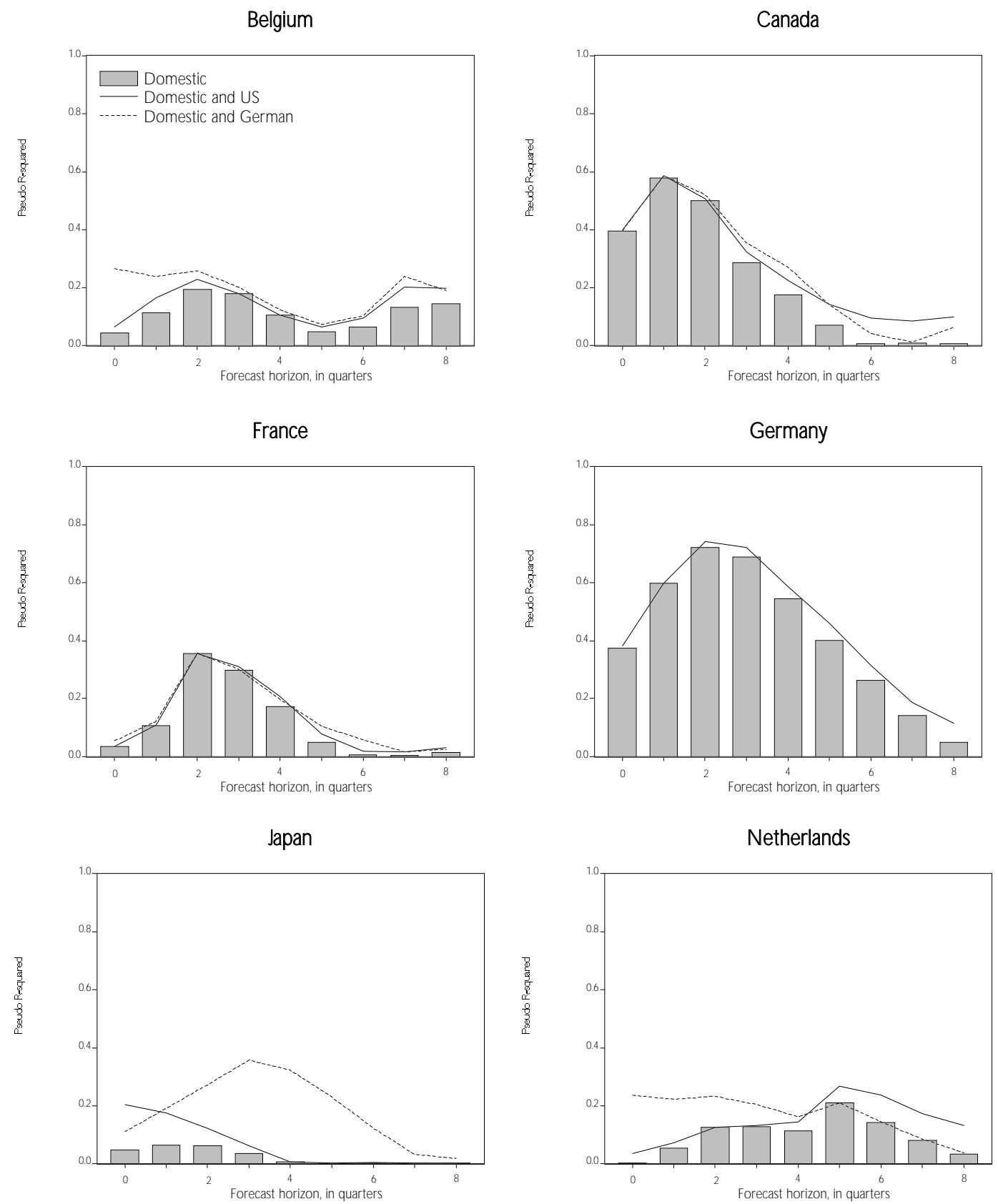

United Kingdom
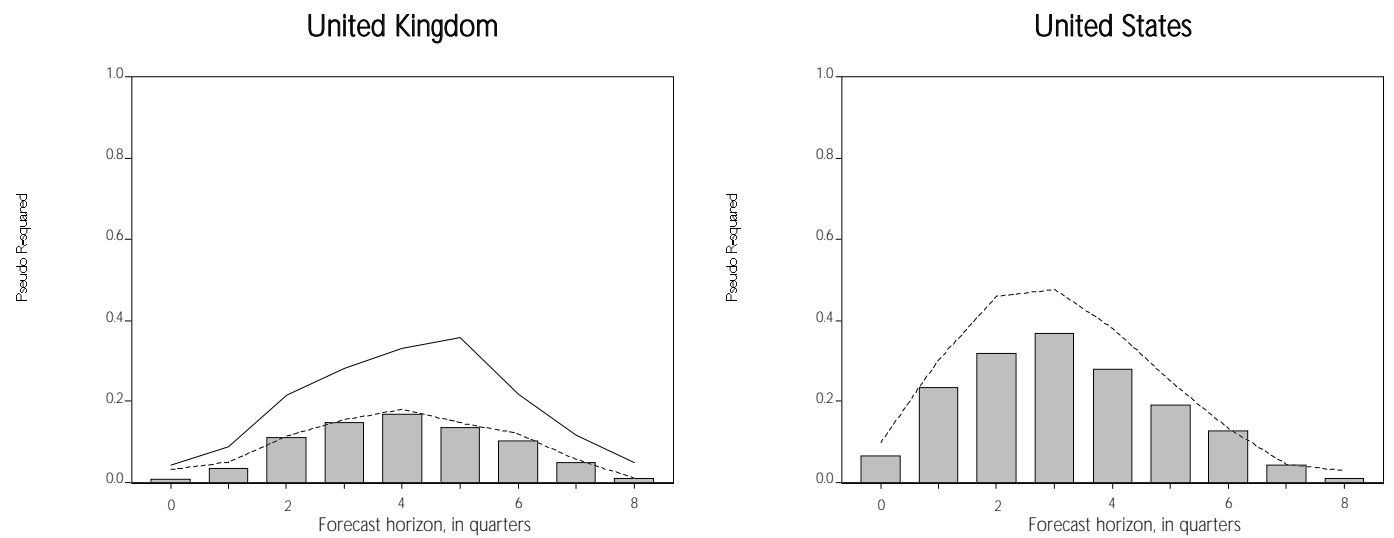
Table 2

Probability of a recession four quarters ahead as a function of the current spread

\begin{tabular}{|c|c|c|c|c|c|c|c|c|}
\hline Spread & Belgium & Canada & France & Germany & Japan & Netherlands & UK & US \\
\hline $4.0 \%$ & 0.10 & 0.02 & 0.06 & 0.00 & 0.19 & 0.21 & 0.05 & 0.00 \\
\hline $3.0 \%$ & 0.18 & 0.04 & 0.11 & 0.02 & 0.20 & 0.28 & 0.09 & 0.02 \\
\hline $2.0 \%$ & 0.29 & 0.09 & 0.17 & 0.07 & 0.22 & 0.36 & 0.14 & 0.08 \\
\hline $1.0 \%$ & 0.43 & 0.16 & 0.25 & 0.20 & 0.24 & 0.44 & 0.21 & 0.21 \\
\hline $0.0 \%$ & 0.57 & 0.25 & 0.34 & 0.41 & 0.25 & 0.53 & 0.30 & 0.41 \\
\hline$-1.0 \%$ & 0.71 & 0.37 & 0.45 & 0.66 & 0.27 & 0.62 & 0.40 & 0.64 \\
\hline$-2.0 \%$ & 0.82 & 0.51 & 0.56 & 0.85 & 0.29 & 0.70 & 0.51 & 0.83 \\
\hline$-3.0 \%$ & 0.90 & 0.64 & 0.66 & 0.95 & 0.31 & 0.77 & 0.62 & 0.94 \\
\hline$-4.0 \%$ & 0.95 & 0.76 & 0.76 & 0.99 & 0.33 & 0.83 & 0.72 & 0.98 \\
\hline
\end{tabular}

Note: These probabilities are calculated from the probit equations reported in Table 1.

To interpret the results in Table 2, consider first the case of Germany, the country for which the predictive power of the spread appears the strongest. Suppose first that long interest rates are $4 \%$ above short interest rates, so that the spread is $4 \%$. The table indicates that the probability that a recession will occur in four quarters' time is $0 \%$. However, as short rates rise relative to long rates, the probability of a recession increases as well. Thus, when the spread is $2 \%$, the probability is $7 \%$, and when the spread is $0 \%$ the probability is $41 \%$. Note, furthermore, that as the spread turns increasingly negative the probabilities rise quickly. When short rates are $1 \%$ above long rates, the probability of a recession rises to $66 \%$. When the spread is $-2 \%$, the probability is $85 \%$. Finally, at a spread of $-4 \%$ the probability that the economy will be in a recession in four quarters is $99 \%$.

Turning to the other countries, the table suggests that, in general, downward-sloping yield curves have historically been associated with subsequent recessions. The exception to this rule is Japan, for which the spreads show little association with realised future recessions. One possible explanation for the lack of a significant relationship is that tight regulation of Japanese financial markets during the first part of the sample period limited the role of market expectations in the determination of interest rates. Alternatively, the lack of a strong relationship in the Japanese data between the slope of the term structure and recessions may be due to the fact that Japan has experienced fewer and shallower recessions than the other countries we study. 


\subsection{International differences}

The review of the empirical results raises the question of what the sources of the observed differences in the predictive ability of the spreads are. Three explanations come readily to mind.

First, it may be inappropriate to use the same criteria to define recessions in a crosssection of countries. For instance, suppose that there are measurement errors in the industrial production data used by Artis et al. (1995), and that these measurement errors are more pronounced in some countries than in others. ${ }^{11}$ In this case, there could be spurious indications of recessions in some countries, which would tend to obscure the true relationship between spreads and recessions.

Second, the cross-country variation may be due to differences in the regulation of financial markets. For instance, interest rates in the United States, Germany and Canada have historically been relatively freely determined. In contrast, financial markets in Japan were relatively heavily regulated until the early 1980s. These differences may cause interest rates in the first part of the sample not to reflect accurately financial market participants' expectations about the future course of the economy.

Third, the choice of exchange rate regime may also affect the information content of the term structure. For instance, foreign exchange market pressures have at times forced policy-makers to increase short-term interest rates to maintain the exchange rate parity. Since such increases tend to be large and temporary (and therefore not necessarily tightly linked to the future state of the economy), exchange-market-induced changes in interest rates could also obscure the relationship between the slope of the term structure and the probability of a recession.

Since both interest rates and recessions tend to be correlated across countries, the question naturally arises as to whether the slope of foreign term structures helps predict recessions in the domestic economy, as suggested by the work of Plosser and Rouwenhorst (1994). This is the issue we explore next.

\subsection{Evidence for foreign term spreads}

In this section we re-estimate equation (1), but incorporate a foreign term spread as a second explanatory variable. Given the importance of macroeconomic developments in the United States and Germany for economic conditions elsewhere, we focus our attention on the spreads in these two countries. Thus, Table 3 provides estimates using both the domestic spread and the spread in the United States as regressors, and Table 4 provides the results using the German spread as the second regressor.

Consider first the results in Table 3. Note first that the US spread is significant in at least one regression per country (except for Japan, where the sign of the US spread is positive, which suggests a spurious correlation). The results for the United Kingdom are particularly striking: the US

11 An alternative problem could be differences in the construction of industrial production indicators, for instance in the number of sectors of the economy that are covered. 
Table 3

Pseudo $\mathbf{R}^{2}$ and $t$-statistics for probit models using domestic and US spreads

Sample period: 1972:1-1993:4

\begin{tabular}{|c|c|c|c|c|c|c|c|c|c|}
\hline \multirow[b]{3}{*}{ Belgium $^{1}$} & \multicolumn{9}{|c|}{ Number of quarters ahead $(k)$} \\
\hline & 0 & 1 & 2 & 3 & 4 & 5 & 6 & 7 & 8 \\
\hline & & & & & & & & & \\
\hline Pseudo $\mathrm{R}^{2}$ & 0.064 & 0.165 & 0.228 & 0.180 & 0.106 & 0.064 & 0.094 & 0.201 & 0.197 \\
\hline Domestic spread $^{2}$ & $-2.0 * *$ & $-3.2 * * *$ & $-3.6 * * *$ & -3.0 ***: & $-2.3^{* *}$ & -0.6 & 0.6 & $2.2 * *$ & $2.1 * *$ \\
\hline US spread $^{2}$ & 1.2 & $1.8^{*}$ & 1.5 & 0.1 & -0.1 & -1.0 & -1.4 & $-2.1 * *$ & $-1.9^{*}$ \\
\hline Log likelihood & -42.0 & -38.4 & -36.2 & -37.9 & -40.5 & -42.0 & -41.0 & -37.4 & -37.7 \\
\hline Canada ............. & & & & & & & & & \\
\hline Pseudo $\mathrm{R}^{2}$ & 0.400 & 0.586 & 0.505 & 0.322 & 0.225 & 0.142 & 0.094 & 0.085 & 0.100 \\
\hline Domestic spread $^{2}$ & $-4.0 * * *$ & $-4.2 * * *$ & -3.6 ***, & $-2.3 * *$ & -1.4 & 0.0 & 1.4 & $2.4 * *$ & $2.8 * * *$ \\
\hline US spread $^{2}$ & 0.7 & 0.9 & -0.7 & $-1.8^{*}$ & $-2.1 * *$ & $-2.5 * *$ & $-2.7 * * *$ & $-2.5 * *$ & $-1.8^{*}$ \\
\hline Log likelihood & -32.4 & -23.5 & -27.4 & -36.0 & -40.5 & -44.2 & -46.4 & -46.8 & -46.1 \\
\hline France ............. & & & & & & & & & \\
\hline Pseudo $\mathrm{R}^{2}$ & 0.035 & 0.108 & 0.355 & 0.309 & 0.208 & 0.077 & 0.018 & 0.016 & 0.030 \\
\hline Domestic spread $^{2}$ & $-1.8^{*}$ & $-3.0 * * *$ & $-4.4 * * *$ & -4.2 ***: & $-3.2 * * *$ & -1.5 & -0.3 & -0.0 & 1.5 \\
\hline US spread $^{2}$ & 0.4 & 0.4 & 0.3 & -1.0 & $-1.8 *$ & -1.6 & -1.0 & -1.1 & -1.2 \\
\hline Log likelihood & -51.0 & -47.7 & -36.4 & -38.5 & -43.2 & -49.1 & -51.7 & -51.8 & -51.2 \\
\hline Germany ......... & & & & & & & & & \\
\hline Pseudo $\mathrm{R}^{2}$ & 0.383 & 0.598 & 0.742 & 0.720 & 0.586 & 0.460 & 0.315 & 0.187 & 0.115 \\
\hline Domestic spread $^{2}$ & $-5.2 * * *$ & $-5.7 * * *$ & $-5.1 * * *$ & $-5.1 * * *$ & $-5.0 * * *$ & $-4.4 * * *$ & $-3.4 * * *$ & $-2.1 * *$ & -0.5 \\
\hline US spread $^{2}$ & 0.9 & 0.1 & -1.4 & $-1.8^{*}$ & $-2.0^{* *}$ & $-2.3 * *$ & $-2.2 * *$ & $-2.0 * *$ & $-2.3 * *$ \\
\hline Log likelihood & -39.9 & -28.8 & -20.5 & -21.8 & -29.4 & -36.1 & -43.2 & -49.3 & -52.6 \\
\hline Japan & & & & & & & & & \\
\hline Pseudo $\mathrm{R}^{2}$ & 0.203 & 0.176 & 0.122 & 0.062 & 0.005 & 0.002 & 0.003 & 0.001 & 0.001 \\
\hline Domestic spread $^{2}$ & $-3.2 * * *$ & $-3.2 * * *$ & $-2.9 * * *$ & $-2.1 * *$ & -0.6 & -0.2 & -0.4 & -0.3 & 0.3 \\
\hline US spread $^{2}$ & $3.1 * * *$ & $2.8 * * *$ & $2.2 * *$ & 1.5 & -0.0 & -0.2 & 0.5 & -0.0 & -0.2 \\
\hline Log likelihood & -41.5 & -42.7 & 45.1 & -47.8 & -50.3 & -50.5 & -50.4 & -50.5 & -50.5 \\
\hline Netherlands ${ }^{1}$ & & & & & & & & & \\
\hline Pseudo $\mathrm{R}^{2}$ & 0.035 & 0.073 & 0.125 & 0.132 & 0.144 & 0.268 & 0.237 & 0.174 & 0.131 \\
\hline Domestic spread $^{2}$ & -0.6 & $-2.1 * *$ & $-2.7 * * *$ & $-2.6^{* * * *}$ & $-2.2 * *$ & $-2.9 * * *$ & $-2.1 * *$ & -1.2 & -0.3 \\
\hline US spread $^{2}$ & 1.5 & 1.1 & 0.1 & -0.6 & -1.4 & $-2.0 * *$ & $-2.4 * *$ & $-2.4 * *$ & $-2.5 * *$ \\
\hline Log likelihood & -45.9 & -44.6 & -42.8 & -42.5 & -42.1 & -37.6 & -38.8 & -41.0 & -42.6 \\
\hline UK & & & & & & & & & \\
\hline Pseudo $\mathrm{R}^{2}$ & 0.044 & 0.088 & 0.216 & 0.281 & 0.330 & 0.357 & 0.218 & 0.117 & 0.050 \\
\hline Domestic spread $^{2}$ & -0.3 & -1.0 & $-2.1 * *$ & $-2.5 * *$ & $-2.6^{* * *}$ & $-2.1 * *$ & $-1.8^{*}$ & -1.2 & -0.2 \\
\hline US spread $^{2}$ & $-1.7 *$ & $-2.1 * *$ & $-3.0 * * *$ & $-3.4 * * *$ & $-3.7 * * *$ & -4.2 *** & $-3.2 * * *$ & $-2.5 * *$ & $-1.9 *$ \\
\hline Log likelihood & -53.1 & -51.1 & -45.3 & -42.3 & -40.0 & -38.6 & -45.2 & -49.9 & -52.9 \\
\hline
\end{tabular}

${ }^{1}$ Sample period: 1977:1-1993:4.

2 t-statistics; $*$, ** and $* * *$ denote significance at the $10 \%, 5 \%$ and $1 \%$ level respectively. 
Table 4

Pseudo $\mathbf{R}^{2}$ and t-statistics for probit models using domestic and German spreads

Sample period: 1972:1-1993:4

\begin{tabular}{|c|c|c|c|c|c|c|c|c|c|}
\hline \multirow[b]{3}{*}{ Belgium $^{1} \ldots \ldots$} & \multicolumn{9}{|c|}{ Number of quarters ahead $(k)$} \\
\hline & 0 & 1 & 2 & 3 & 4 & 5 & 6 & 7 & 8 \\
\hline & & & & & & & & & \\
\hline Pseudo $\mathrm{R}^{2}$ & 0.266 & 0.238 & 0.258 & 0.201 & 0.123 & 0.073 & 0.102 & 0.239 & 0.190 \\
\hline Domestic spread $^{2}$ & 1.4 & -0.2 & $2.0 * *$ & $-2.3 * *$ & $-2.0 * *$ & -0.4 & 0.7 & $2.4^{* *}$ & $1.9^{*}$ \\
\hline German spread $^{2}$ & $-3.7 * * *$ & $-2.9 * * *$ & $-2.2 * *$ & -1.3 & -1.1 & -1.3 & -1.6 & $-2.5^{* *}$ & $-1.7 *$ \\
\hline Log likelihood & -34.8 & -35.8 & -35.1 & -37.1 & -39.9 & -41.7 & -40.7 & -36.1 & -37.9 \\
\hline Canada .......... & & & & & & & & & \\
\hline Pseudo $\mathrm{R}^{2}$ & 0.396 & 0.585 & 0.521 & 0.354 & 0.270 & 0.141 & 0.041 & 0.012 & 0.063 \\
\hline Domestic spread $^{2}$ & $-4.6^{* * * *}$ & $-4.9 * * *$ & $-4.7 * * *$ & $-3.7 * * *$ & $-2.6^{* * * *}$ & -1.4 & 0.2 & 1.0 & $1.9^{*}$ \\
\hline German spread $^{2}$ & 0.2 & -0.9 & -1.4 & $-2.4 * *$ & $-2.8 * * *$ & $-2.4 * *$ & $-1.7 *$ & -0.6 & 0.4 \\
\hline Log likelihood & -32.6 & -23.5 & -26.6 & -34.6 & -38.4 & -44.3 & -48.7 & -50.0 & -47.8 \\
\hline France ............ & & & & & & & & & \\
\hline Pseudo $\mathrm{R}^{2}$ & 0.054 & 0.121 & 0.356 & 0.301 & 0.197 & 0.104 & 0.058 & 0.016 & 0.025 \\
\hline Domestic spread $^{2}$ & -0.8 & $-2.1 * *$ & $-3.7 * * *$ & $-3.4^{* * * *}$ & $-2.4 * *$ & -0.7 & 0.4 & 0.1 & 1.3 \\
\hline German spread $^{2}$ & -1.3 & -1.2 & 0.3 & -0.5 & -1.5 & $-2.2 * *$ & $-2.1 * *$ & -1.1 & -0.9 \\
\hline Log likelihood & -50.1 & -47.1 & -36.3 & -38.9 & -43.7 & -47.9 & -50.0 & -51.8 & -51.4 \\
\hline Japan .............. & & & & & & & & & \\
\hline Pseudo $\mathrm{R}^{2}$ & 0.110 & 0.190 & 0.272 & 0.357 & 0.322 & 0.229 & 0.122 & 0.031 & 0.018 \\
\hline Domestic spread $^{2}$ & -1.5 & $-1.7^{*}$ & -1.5 & -0.5 & 0.7 & 1.0 & 0.7 & 0.2 & 0.7 \\
\hline German spread $^{2}$ & $-2.3 * *$ & $-3.2 * * *$ & $-4.0 * * *$ & $-4.5^{* * * * 1}$ & $-4.5^{* * * *}$ & $-4.0 * * *$ & $-3.1 * * *$ & -1.6 & -1.2 \\
\hline Log likelihood & -45.6 & -42.1 & -38.4 & -34.4 & -36.0 & -40.3 & -45.1 & -49.2 & -49.8 \\
\hline Netherlands 1 & & & & & & & & & \\
\hline Pseudo $\mathrm{R}^{2}$ & 0.235 & 0.222 & 0.232 & 0.203 & 0.162 & 0.209 & 0.144 & 0.084 & 0.037 \\
\hline Domestic spread $^{2}$ & $2.4 * *$ & 1.0 & -0.9 & -1.0 & -1.1 & $-2.4 * *$ & $-2.3 * *$ & $-2.0 *$ & -1.5 \\
\hline German spread $^{2}$ & $-3.5^{* * * *}$ & $-3.1 * * *$ & $-2.7 * * *$ & $-2.3 * *$ & $-1.8 *$ & -0.2 & 0.4 & 0.5 & 0.5 \\
\hline Log likelihood & -38.8 & -39.3 & -39.0 & -40.0 & -41.5 & -39.8 & -42.1 & -44.2 & -45.9 \\
\hline UK ................. & & & & & & & & & \\
\hline Pseudo $\mathrm{R}^{2}$ & 0.032 & 0.050 & 0.114 & 0.155 & 0.180 & 0.147 & 0.120 & 0.057 & 0.011 \\
\hline Domestic spread $^{2}$ & -0.1 & -1.0 & $-2.5 * *$ & $-2.7 * * *$ & $-2.9 * * *$ & $-2.5 * *$ & $-2.0 * *$ & -1.4 & -0.7 \\
\hline German spread $^{2}$ & -1.4 & -1.1 & -0.5 & -0.8 & -1.0 & -1.0 & -1.3 & -0.9 & -0.3 \\
\hline Log likelihood & -53.6 & -52.8 & -49.9 & -48.1 & -47.0 & -48.5 & -49.7 & -52.5 & -54.6 \\
\hline United States & & & & & & & & & \\
\hline Pseudo $\mathrm{R}^{2}$ & 0.098 & 0.301 & 0.459 & 0.476 & 0.380 & 0.250 & 0.133 & 0.045 & 0.029 \\
\hline Domestic spread $^{2}$ & -1.5 & $-3.2 * * *$ & $-3.6^{* * * * 1}$ & $-3.9 * * *$ & $-3.2 * * *$ & $-2.6 * *$ & $-2.4 * *$ & $-1.8^{*}$ & -1.5 \\
\hline German spread $^{2}$ & $-1.7^{*}$ & $-2.4 * *$ & $-3.2 * * *$ & $-2.9 * * *$ & $-2.9 * * *$ & $-2.2 * *$ & 0.6 & 0.2 & 1.3 \\
\hline Log likelihood & -45.1 & -36.0 & -28.7 & -27.8 & -32.4 & -38.3 & -43.6 & -47.5 & -48.2 \\
\hline
\end{tabular}

${ }^{1}$ Sample period: 1977:1-1993:4.

2 t-statistics; $*$, ** and $* * *$ denote significance at the $10 \%, 5 \%$ and $1 \%$ level respectively. 
spread enters significantly for all forecast horizons. Spreads in the United States also enter significantly for longer $k \mathrm{~s}$ in Canada, Germany and the Netherlands. ${ }^{12}$ For France, the results are essentially unaffected when the US spread is introduced.

Next we turn to Table 4, where we have replaced the spread in the United States with the spread in Germany. The most striking finding is that the German spread is significant for $k=0, \ldots, 5$ in the case of the United States, and for $k=0, \ldots, 6$ in Japan. The German spread is also significant for $k=5,6$ in France, and for $k=3, \ldots, 6$ in Canada. In the case of the United Kingdom, however, the German spread never enters significantly in the regressions. With respect to Belgium and the Netherlands, the German spread also enters significantly in the equation. However, the coefficient on the domestic term spread generally turns positive.

To summarise these results, it appears that foreign spreads do contain information about the probability of a future recession that is not contained in domestic spreads. This raises the question as to just how much information they add. To address this question, consider Graph 1, which plots the pseudo $\mathrm{R}^{2}$ for different forecast horizons. As a benchmark, the graph contains the pseudo $\mathrm{R}^{2}$ when only the domestic spread is used. While adding a foreign spread increases the in-sample fit for all countries (as, of course, adding any variable necessarily does), the improvements are substantial only when the German spread is included in the regressions for Japan, and when the US spread is included in the regressions for the United Kingdom. All in all, it appears that including a foreign term spread adds little information beyond that contained in the domestic term spread.

\subsection{Estimated recession probabilities}

So far we have demonstrated that, to varying degrees, term spreads are useful indicators of recession probabilities in all the countries studied. One natural question to ask is how the estimated probabilities have varied during the sample period. In Graph 2 we display the probability that the economy will be in recession in a given quarter on the basis of the interest rate spread(s) observed four quarters earlier. ${ }^{13}$ Ideally, the probability should be zero in the non-recession quarters and 1 in the recession quarters, which are shaded in the graph. The probabilities are estimated first using solely the domestic interest rate spread and then including the term spread either in the United States or Germany.

Consider the results for Germany. The graph indicates that the estimated recession probabilities are high in the quarters when recessions occurred and low in the non-recession quarters. There were two exceptions in 1972 and 1990. In both cases, however, recessions did follow at a somewhat later date. Thus, the term structure appears to give few "false alarms", at least in the case of Germany.

12 They are also significant for $k=7,8$ in Belgium. However, the sign on the Belgian interest spread turns positive when the US spread is entered in the regression.

13 It should be kept in mind that the predictive ability depends on the forecast horizon: for shorter horizons the predictive ability would have been somewhat higher. 
Two aspects of the results for the other countries are of interest. Note the large improvement in the results for Japan when the German spread is included. As can be seen, the Japanese spread contains essentially no information useful for predicting recessions four quarters ahead, but adding the German spread improves the results considerably. Note, however, that the recession in 1985:2-1986:2 is missed by the German spread. This suggests that the German spread is useful for predicting Japanese recessions in-sample because recession in Germany and Japan tended to coincide, and not because a steepening of the German yield curve triggers recessions in Japan.

Note also that when the US spread is included in the regressions for the United Kingdom the improvement in the fit appears largest in the 1970s. Since financial market liberalisation in the United Kingdom started in the early 1980s, this finding suggests that regulatory differences may explain differences between countries in the predictive ability of the spread.

\subsection{Leading indicators}

Finally, we turn to the important question of whether the information implicit in the term structure of interest rates is additional to that contained in leading indicators. Table 5 shows that while leading indicators enter with significant coefficients in the probit regressions for all countries, they do so only for very short (or zero) forecast horizons: only in Belgium and the Netherlands do they contain information useful for predicting recessions three quarters ahead. Note that the term spread does contain information useful for predicting recession further ahead in all countries except Japan. Thus, as found by Estrella and Mishkin (1995a) for US data, the term spread seems to provide considerably more forewarning than leading indicators about the likelihood of a recession.

In Graph 3 we show plots of the pseudo $\mathrm{R}^{2}$ for probit regressions using the domestic spread with and without leading indicators. The graph illustrates that only the near-term predictive ability is increased by adding an index of leading indicators to the regressions. 
Graph 2

Forecasting probability of recession in the current quarter, using term spread four quarters earlier
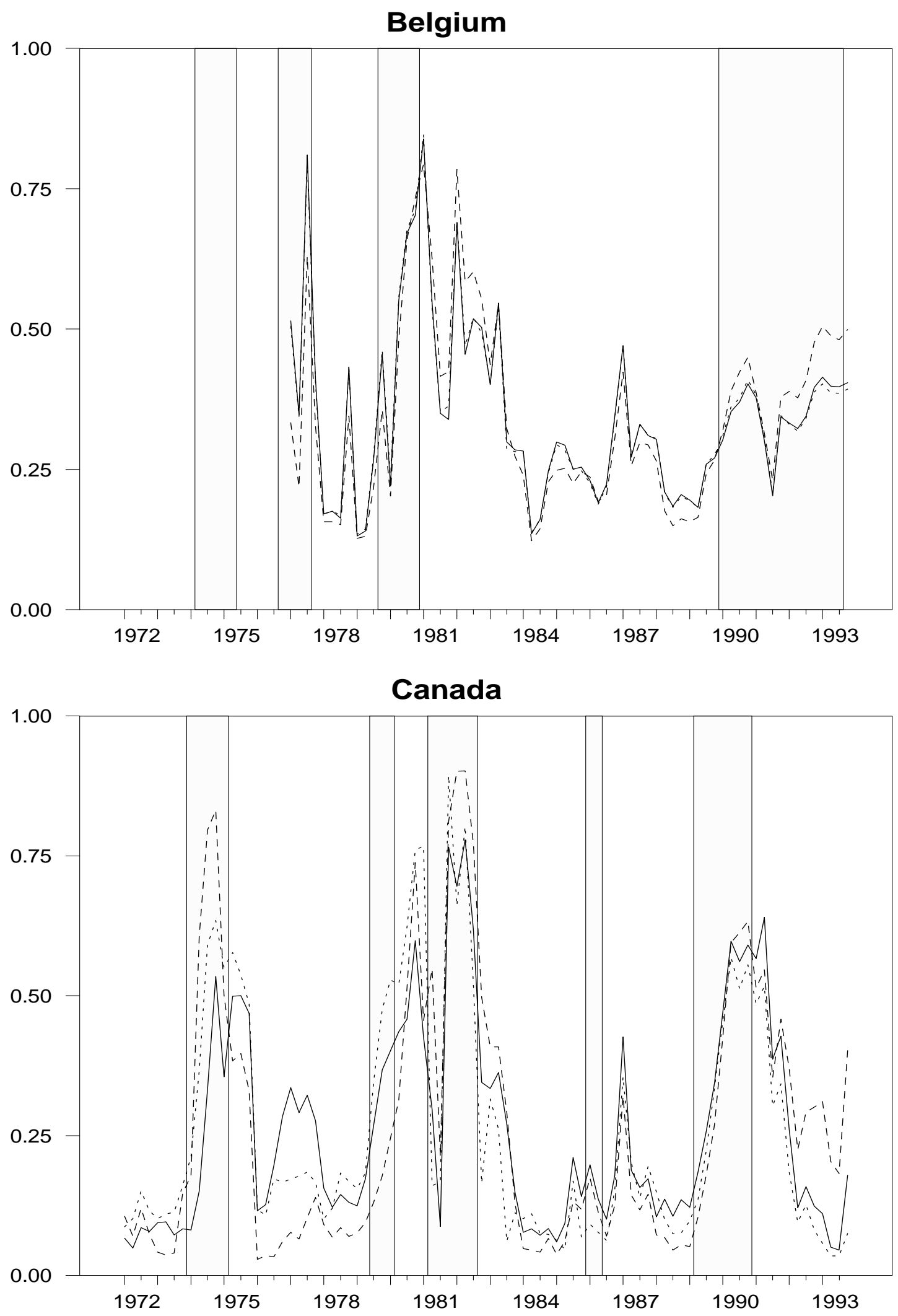


\section{France}
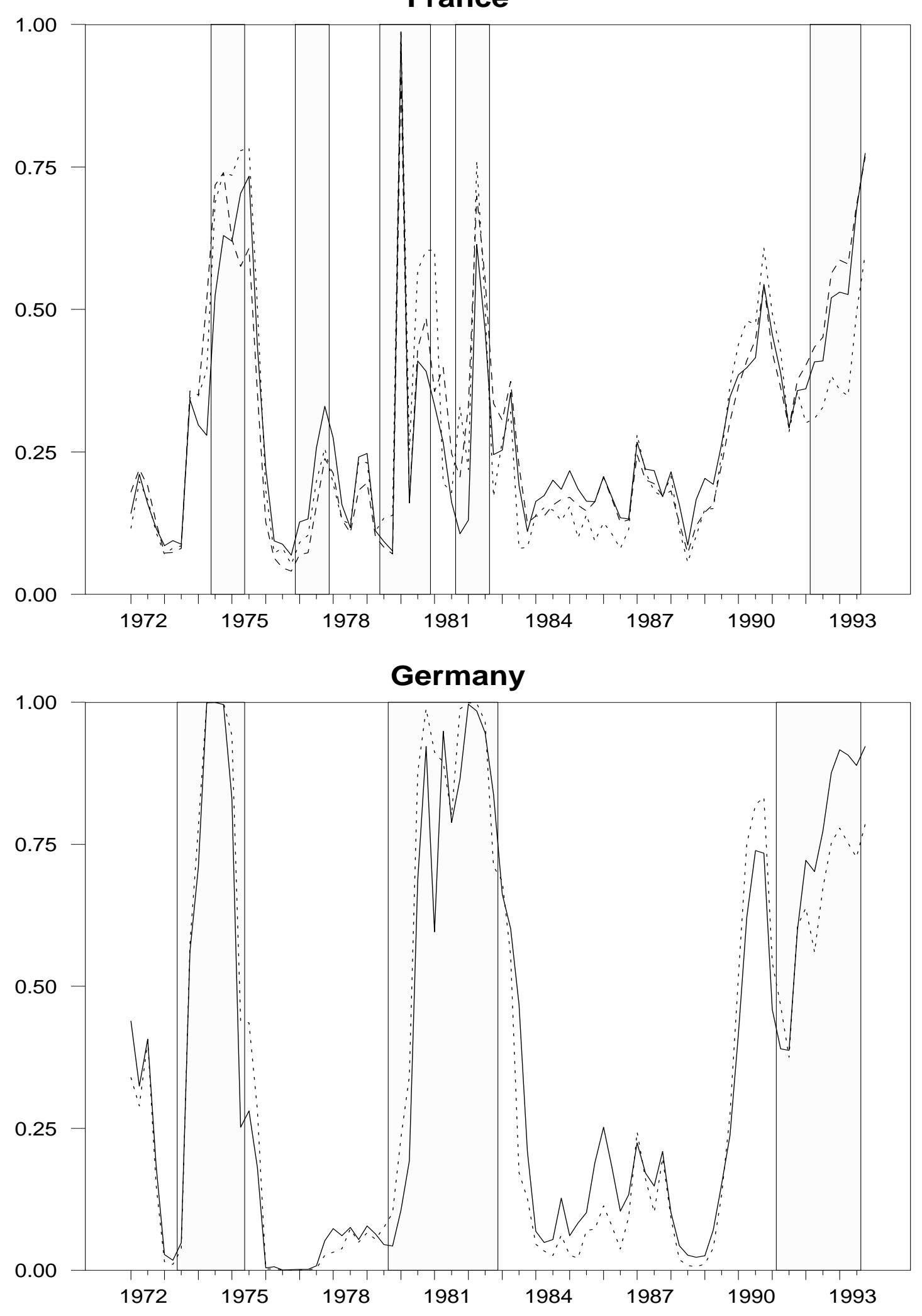

Key: ___ Domestic spread _.... Domestic and US spreads _---- Domestic and German spreads 
Graph 2 (cont.)
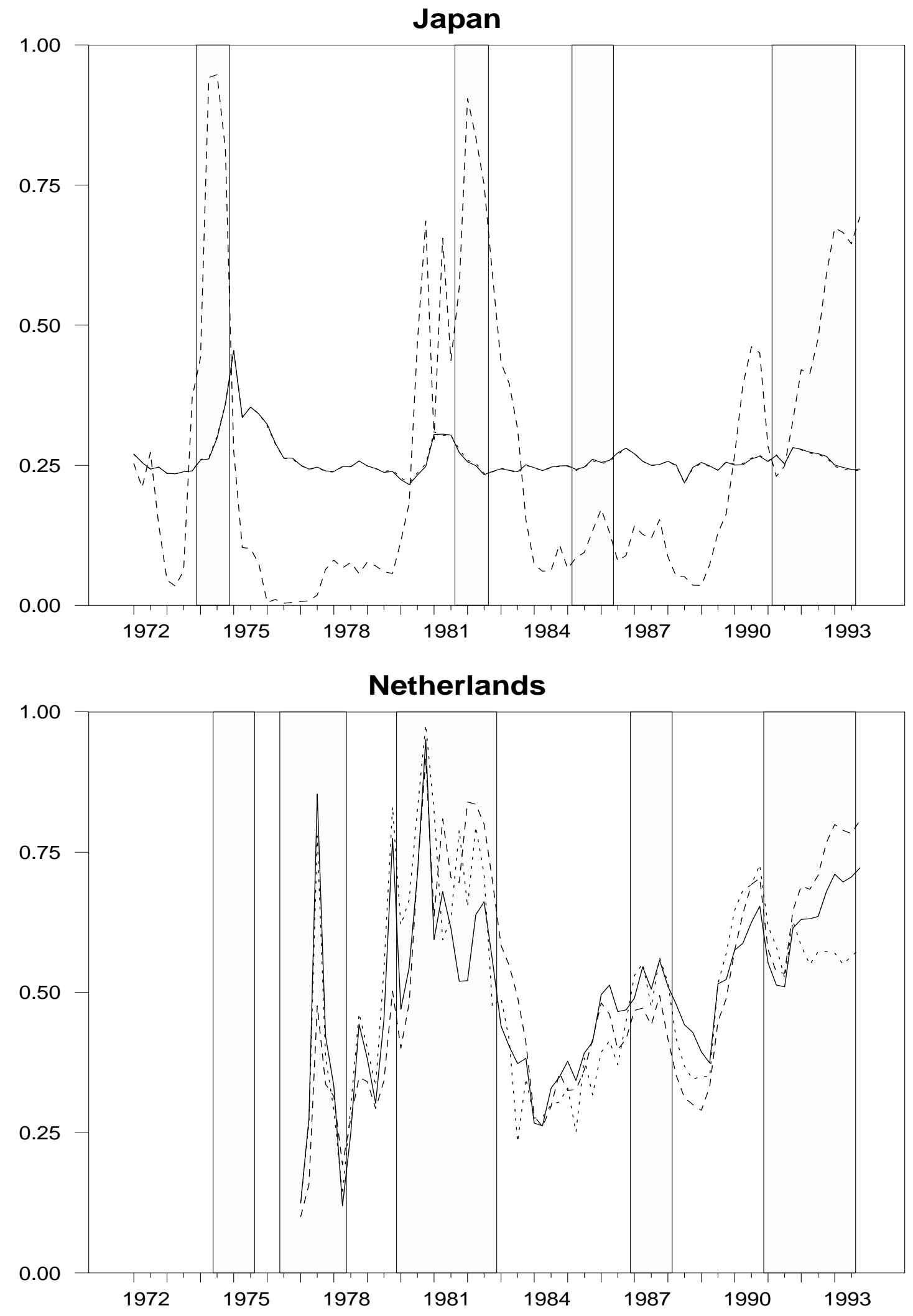

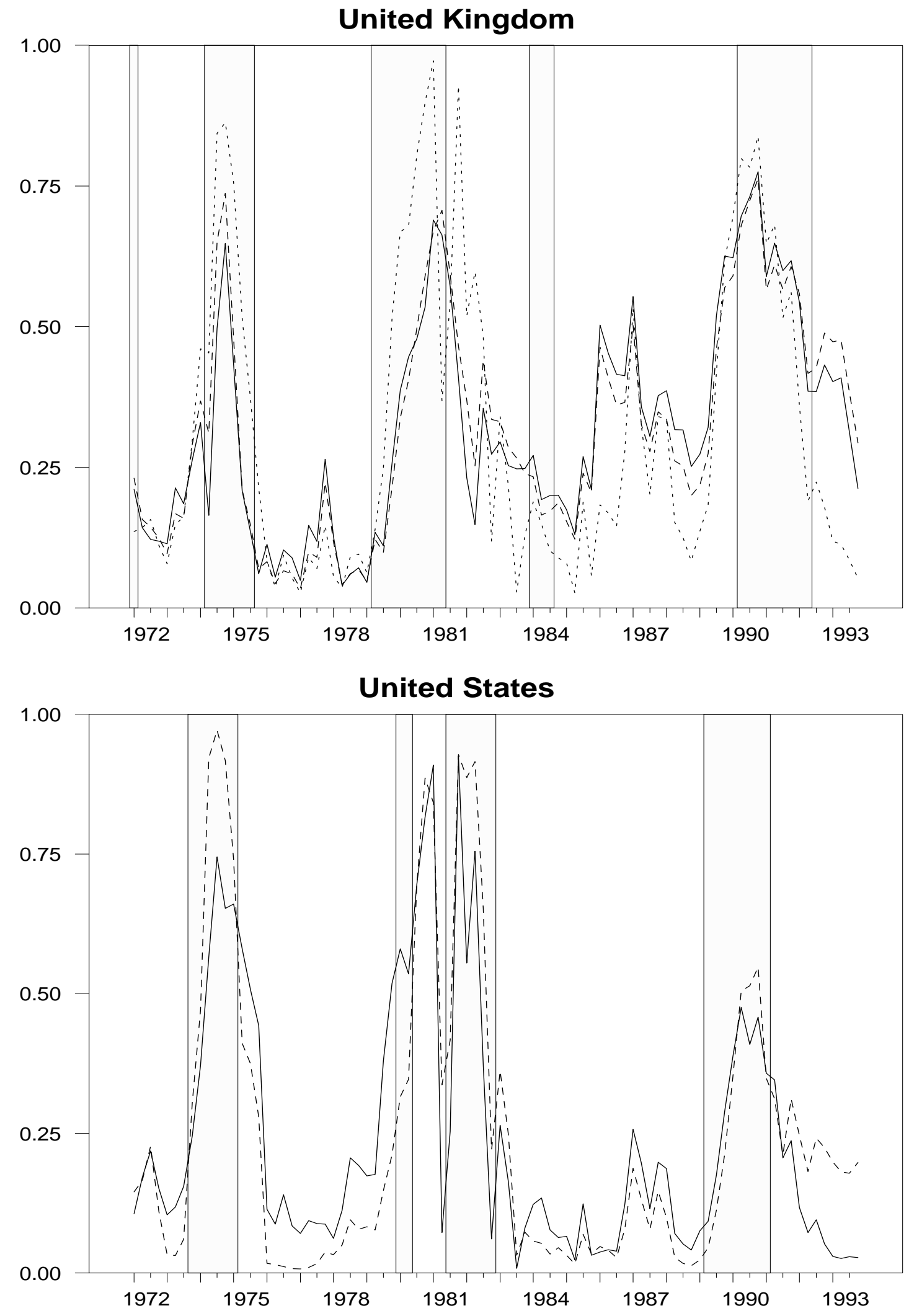

Key: __ Domestic spread _.... Domestic and US spreads _---- Domestic and German spreads 
Table 5

Pseudo $\mathbf{R}^{2}$ and $\mathbf{t}$-statistics for probit models using domestic spread and leading indicator

Sample period: 1972:1-1993:4

\begin{tabular}{|c|c|c|c|c|c|c|c|c|c|}
\hline \multirow{3}{*}{ Belgium $^{1} \ldots \ldots$} & \multicolumn{9}{|c|}{ Number of quarters ahead $(k)$} \\
\hline & 0 & 1 & 2 & 3 & 4 & 5 & 6 & 7 & 8 \\
\hline & & & & & & & & & \\
\hline Pseudo $\mathrm{R}^{2}$ & 0.277 & 0.307 & 0.276 & 0.224 & 0.107 & 0.051 & 0.066 & 0.134 & 0.146 \\
\hline Domestic spread $^{2}$ & $-1.7 *$ & $-2.7 * * *$ & $-3.2 * * *$ & $-3.1 * * *$ & $-2.6 * * *$ & -1.1 & 0.0 & 1.4 & 1.4 \\
\hline Leading indicator $^{2}$ & $-3.4 * * * *$ & $-3.2 * * *$ & $-2.3 * *$ & $-1.8^{*}$ & -0.2 & 0.4 & 0.3 & -0.4 & -0.3 \\
\hline Log likelihood & -34.4 & -33.3 & -34.4 & -36.3 & -40.4 & -42.4 & -41.9 & -39.7 & -39.4 \\
\hline \multicolumn{10}{|l|}{ Canada .......... } \\
\hline Pseudo $\mathrm{R}^{2}$ & 0.704 & 0.638 & 0.503 & 0.292 & 0.189 & 0.069 & 0.009 & 0.018 & 0.095 \\
\hline Domestic spread $^{2}$ & $-3.9 * * *$ & $-4.9 * * *$ & $-4.9 * * *$ & $-4.4 * * *$ & $-3.8 * * *$ & $-2.3^{* *}$ & -0.5 & 1.0 & $2.4^{* *}$ \\
\hline Leading indicator ${ }^{2}$ & $-3.9 * * *$ & $-2.3^{* *}$ & 0.6 & 0.7 & 1.1 & 0.1 & -0.5 & -0.4 & -1.3 \\
\hline Log likelihood & -17.5 & -20.9 & -27.5 & -37.4 & -42.1 & -47.5 & -50.1 & -49.7 & -46.4 \\
\hline \multicolumn{10}{|l|}{ France ........... } \\
\hline Pseudo $\mathrm{R}^{2}$ & 0.181 & 0.340 & 0.429 & 0.298 & 0.180 & 0.069 & 0.010 & 0.018 & 0.031 \\
\hline Domestic spread $^{2}$ & -1.0 & $-2.3^{* *}$ & $-3.9 * * *$ & $-4.1 * * *$ & $-3.6 * * *$ & $-2.2 * *$ & -0.8 & -0.7 & 1.0 \\
\hline Leading indicator $^{2}$ & $-3.4 * * *$ & -4.1 *** & $-2.5^{* *}$ & -0.1 & 0.8 & 1.3 & 0.6 & 0.8 & -0.6 \\
\hline Log likelihood & -44.4 & -37.1 & -32.9 & -39.0 & -44.4 & -49.4 & -52.1 & -51.7 & -51.2 \\
\hline \multicolumn{10}{|l|}{ Germany ........ } \\
\hline Pseudo $\mathrm{R}^{2}$ & 0.573 & 0.814 & 0.782 & 0.701 & 0.547 & 0.418 & 0.282 & 0.185 & 0.110 \\
\hline Domestic spread $^{2}$ & -3.7 *** & $-4.1 * * *$ & $-4.4 * * *$ & $-4.9 * * *$ & $-5.0 * * *$ & $-4.8 * * *$ & $-4.3 * * *$ & $-3.6 * * *$ & $-2.7 * * *$ \\
\hline Leading indicator ${ }^{2}$ & $-4.0 * * * *$ & -3.4 *** & $-2.5^{* *}$ & -1.2 & 0.5 & 1.3 & 1.4 & 1.4 & 1.5 \\
\hline Log likelihood & -30.1 & -16.0 & -18.0 & -23.0 & -31.5 & -38.2 & -44.8 & -49.4 & -52.9 \\
\hline \multicolumn{10}{|l|}{ Japan .............. } \\
\hline Pseudo $\mathrm{R}^{2}$ & 0.152 & 0.118 & 0.089 & 0.044 & 0.019 & 0.013 & 0.001 & 0.009 & 0.016 \\
\hline Domestic spread $^{2}$ & 0.2 & -0.5 & -0.9 & -0.9 & 0.1 & 0.3 & -0.1 & -0.4 & 0.4 \\
\hline Leading indicator ${ }^{2}$ & $-2.8^{* * * *}$ & $-2.1 * *$ & -1.5 & -0.9 & -1.1 & -1.0 & -0.2 & 0.1 & -0.4 \\
\hline Log likelihood & -43.8 & -45.3 & -46.6 & -48.6 & -49.7 & -50.0 & -50.5 & -50.2 & -49.8 \\
\hline \multicolumn{10}{|l|}{ Netherlands ... } \\
\hline Pseudo $\mathrm{R}^{2}$ & 0.176 & 0.259 & 0.287 & 0.245 & 0.128 & 0.209 & 0.154 & 0.083 & 0.036 \\
\hline Domestic spread $^{2}$ & 1.0 & -0.5 & $-1.8^{*}$ & $-2.0 * *$ & $-2.1 * *$ & $-3.1 * * *$ & $-2.9 * * *$ & $-2.2 * *$ & -1.3 \\
\hline Leading indicator ${ }^{2}$ & $-3.1 * * *$ & $-3.3^{* * * * 1}$ & $-3.0 * * *$ & -2.7 **: & -1.0 & 0.2 & 0.9 & 0.4 & -0.4 \\
\hline Log likelihood & -41.0 & -37.9 & -36.9 & -38.4 & -42.7 & -39.8 & -41.8 & -44.3 & -45.9 \\
\hline \multicolumn{10}{|l|}{ UK $\quad \ldots \ldots \ldots \ldots . . . .}$. \\
\hline Pseudo $\mathrm{R}^{2}$ & 0.050 & 0.045 & 0.118 & 0.149 & 0.190 & 0.166 & 0.128 & 0.097 & 0.083 \\
\hline Domestic spread $^{2}$ & -1.6 & $-1.9^{*}$ & $-3.0 * * *$ & $-3.0 * * *$ & $-2.9 * * *$ & $-2.5^{* *}$ & $-2.1 * *$ & -1.3 & 0.1 \\
\hline Leading indicator ${ }^{2}$ & $1.9 *$ & 0.9 & 0.8 & -0.4 & -1.4 & $-1.7^{*}$ & -1.5 & -1.3 & $-1.8^{*}$ \\
\hline Log likelihood & -53.6 & -53.1 & -49.8 & -48.4 & -46.5 & -47.6 & -49.3 & -50.8 & -51.4 \\
\hline \multicolumn{10}{|l|}{ US } \\
\hline Pseudo $\mathrm{R}^{2}$ & 0.319 & 0.363 & 0.364 & 0.368 & 0.280 & 0.192 & 0.130 & 0.050 & 0.011 \\
\hline Domestic spread $^{2}$ & -1.2 & $-3.8 * * *$ & $-4.6^{* * * *}$ & $-4.9 * * *$ & $-4.4 * * *$ & $-3.8 * * *$ & $-3.2 * * *$ & $-2.0^{* *}$ & -1.0 \\
\hline Leading indicator $^{2}$ & $-3.8 * * *$ & $-3.2 * * *$ & $-2.0 * *$ & -0.1 & 0.2 & 0.0 & 0.4 & 0.7 & 0.3 \\
\hline Log likelihood & -35.1 & -33.1 & -33.1 & -32.9 & -37.0 & -40.9 & -43.7 & -47.3 & -49.0 \\
\hline
\end{tabular}

${ }^{1}$ Sample period: 1977:1-1993:4.

2 t-statistics; $*$, ** and $* * *$ denote significance at the $10 \%, 5 \%$ and $1 \%$ level respectively. 
Graph 3

Pseudo $\mathbf{R}^{2}$ as a function of forecast horizon: domestic spread and leading indicator
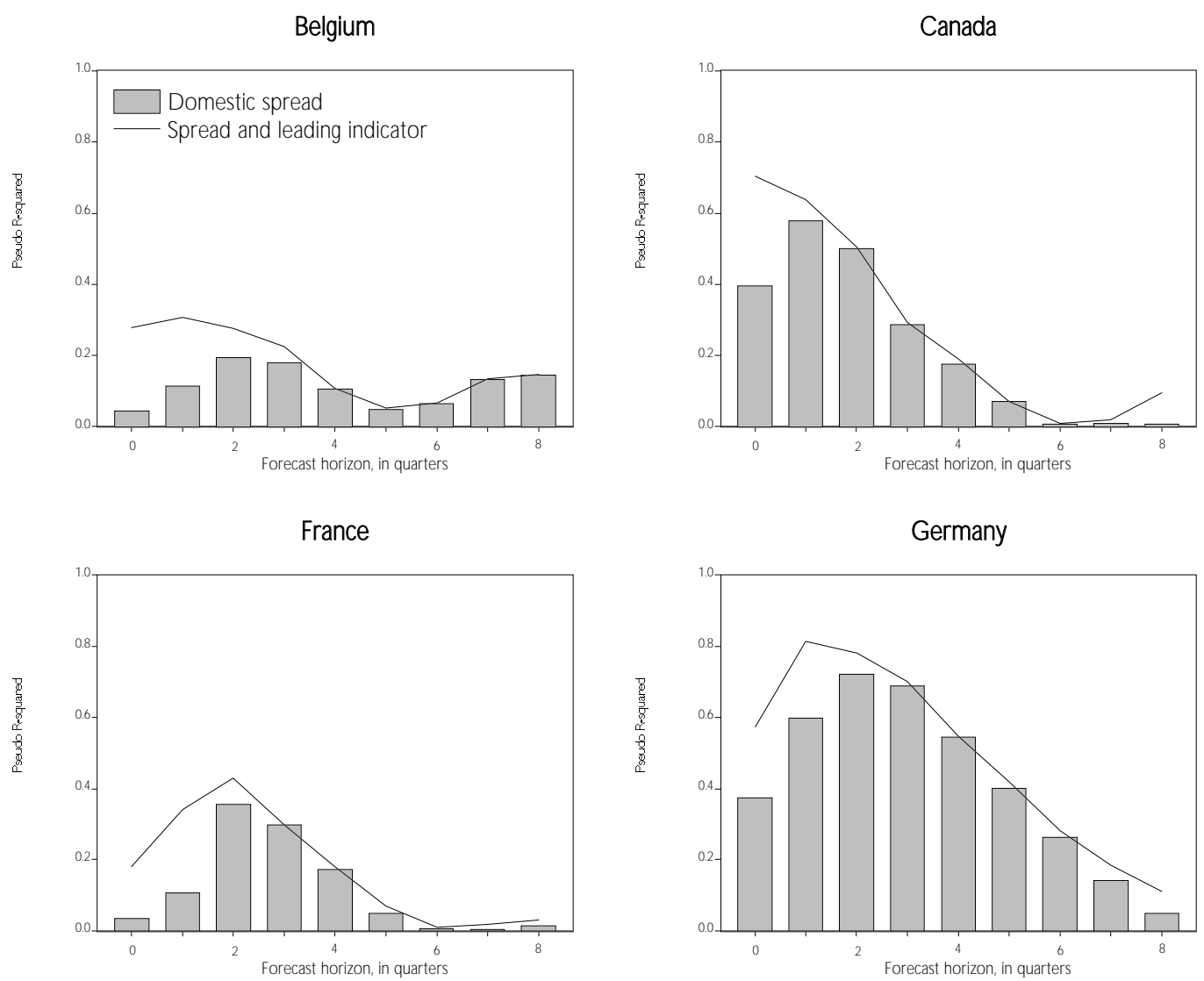

Japan
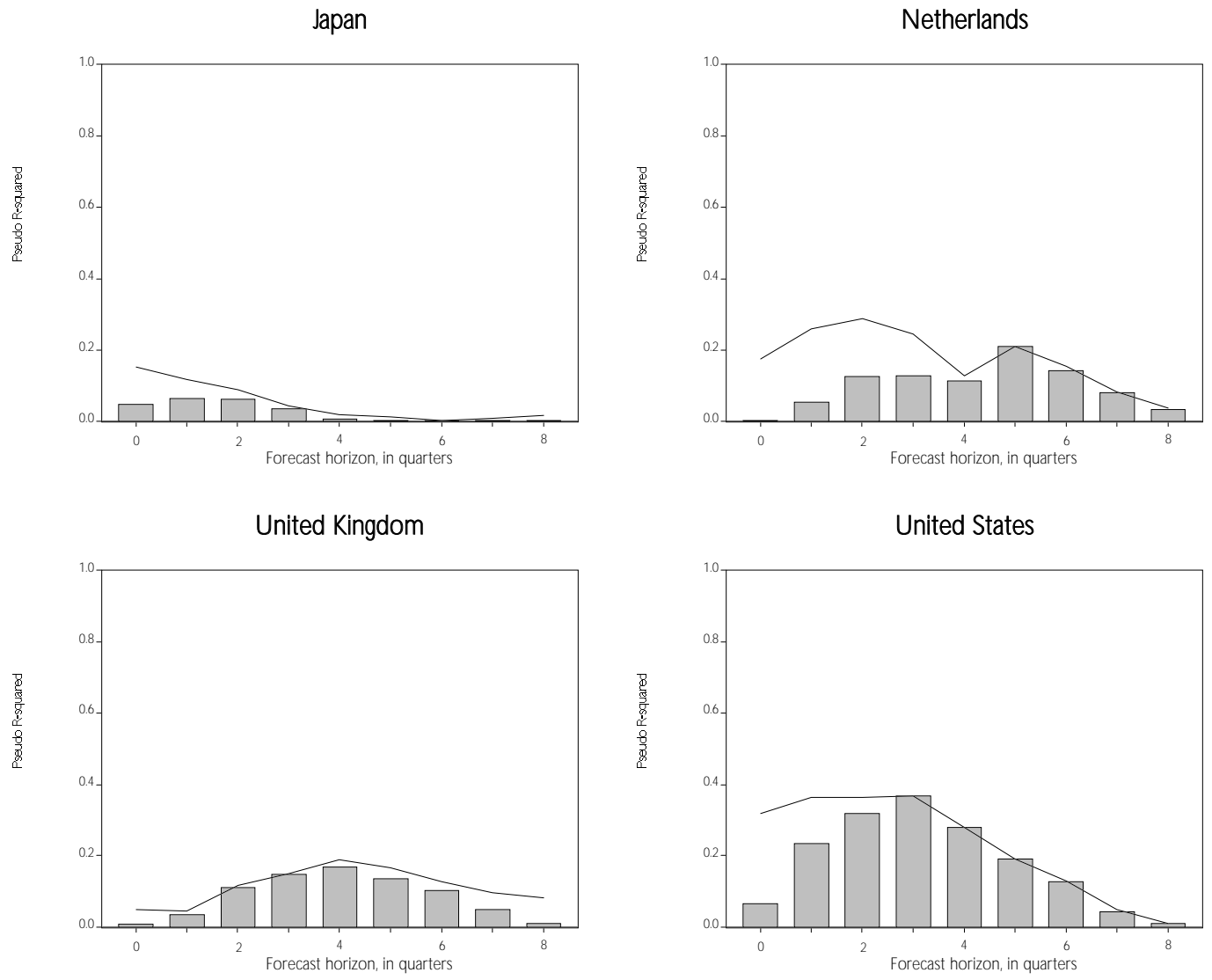


\section{Conclusions}

In this paper we have extended the work in Estrella and Hardouvelis (1991) and Estrella and Mishkin (1995a,b) by studying the ability of the slope of the term structure to predict recessions in eight countries: Belgium, Canada, France, Germany, Japan, the Netherlands, the United Kingdom and the United States. Four findings deserve attention.

First, the slope of the domestic yield curve provides information about the likelihood of a future recession in all eight countries studied. However, there are notable differences between countries: the information content appears to be considerably higher in Canada, Germany and the United States than in the other countries. Moreover, the information content appears relatively limited in Japan. While further research is required to determine why these differences arise, it seems plausible that cross-country variations may be due to differences in the regulation of financial markets, which may have meant that interest rates did not accurately reflect financial market participants' expectations about the future course of the economy.

Second, term spreads in some countries contain information useful for predicting recessions as much as six to eight quarters ahead. The ability to forecast recessions well in advance makes the spread a particularly desirable indicator for monetary policy purposes.

Third, while German and US spreads frequently enter with a significant coefficient in the regressions for the other countries, the pseudo $\mathrm{R}^{2}$ suggests that the added information is limited. The exception to this is Japan, for which German spreads add predictive content, and the United Kingdom, for which spreads in the United States add information.

Fourth, while leading indicators contain information not included in the term spread, this information is useful only for forecasting recessions in the immediate future. Thus, the ability of the spreads to signal recessions further ahead is not affected.

The findings reported above provide further evidence of the potential usefulness of termspreads as indicators for monetary policy purposes. Despite this, it is clear that the econometric results need to be viewed as tentative. One reason why this is so is that many, if not most, recessions in the sample period appear to follow periods in which central banks have attempted to reduce inflationary pressures. But inflation rates fell in the early 1990s to around $2 \%$ in all the countries studied here in response to increased recognition among central banks that a low rate of inflation is the appropriate target for policy. To the extent that this fall in inflation rates is indicative of a permanent change in the monetary policy regime in the OECD countries, the usefulness of the term spread as a predictor of future real economic conditions may have changed. Only time, and further research, will tell. 


\section{Data Appendix}

The measure of fit

The pseudo $\mathrm{R}^{2}$ proposed by Estrella (1995) is given by

$$
1-\left(\frac{\log L_{u}}{\log L_{c}}\right)^{-\frac{2}{n} \log L_{c}}
$$

where $L_{u}$ denotes the likelihood of the estimated model, $L_{c}$ the likelihood of a model incorporating solely a constant as regressor, and $n$ the number of observations.

\section{Recession dates}

The recession dates stem from Artis et al. (1995). In converting from monthly to quarterly dates, a quarter is said to be in recession if the last month of the quarter is in recession. The dates are as follows:

\begin{tabular}{|l|ll|}
\hline Belgium & $1974: 2-1975: 2 ; 1976: 4-1977: 3 ; 1979: 4-1980: 4 ;$ \\
& $1990: 1-1993: 4$ & \\
\hline Canada & $1970: 1-1970: 4 ; 1974: 1-1975: 1 ; 1979: 3-1980: 1 ;$ \\
& $1981: 2-1982: 3 ; 1986: 1-1986: 2 ; 1989: 2-1990: 4$ \\
\hline France & $1974: 3-1975: 2 ; 1977: 1-1977: 4 ; 1979: 3-1980: 4 ;$ \\
& $1981: 4-1982: 3 ; 1992: 2-1993: 4$ \\
\hline Germany & $1973: 3-1975: 2 ; 1979: 4-1982: 4 ; 1991: 2-1993: 4$ \\
& & \\
\hline Japan & $1974: 1-1974: 4 ; 1981: 4-1982: 3 ; 1985: 2-1986: 2 ;$ \\
\hline Netherlands & $1991: 2-1993: 3$ & \\
& $1974: 3-1975: 3 ; 1976: 3-1978: 2 ; 1980: 1-1982: 4 ;$ \\
\hline United Kingdom & $1987: 1-1988: 1 ; 1991: 1-1993: 3$ \\
& $1971: 1-1972: 1 ; 1974: 2-1975: 3 ; 1979: 2-1981: 2 ;$ \\
\hline United States & $1984: 1-1984: 3 ; 1990: 2-1992: 2$ \\
\hline & $1981: 4-1970: 4 ; 1973: 4-1975: 1 ; 1980: 1-1980: 2 ;$ \\
\hline
\end{tabular}

\section{Data sources}

\section{Short-term interest rates}

Belgium Three-month interbank deposit, average of bid and offered market rates, Banque Nationale de Belgique Monthly Report, Table XIX.3.

Canada Three-month prime corporate paper, Bank of Canada Review, Table F1.

France Three-month interbank offered rate, Bank of France Quarterly Bulletin, Statistical Supplement, Table 4.4. 
Germany Three-month money market rates reported by Frankfurt banks, Deutsche Bundesbank Monthly Report, Table VI.4.

Japan Three-month repos on bonds (Gensaki), Bank of Japan Economic Statistics Monthly, Table 38.

Netherlands Three-month AIBOR (Amsterdam interbank offered rate), unsecured, De Nederlandsche Bank Quarterly Bulletin, Table 9.2.

United Three-month sterling interbank deposit rate: middle market rate as recorded

Kingdom by the Bank of England during the late afternoon, Bank of England Quarterly Bulletin, Table 7.2.

United Three-month Treasury bill rate, secondary market: average of rates quoted by States at least five dealers, Federal Reserve Bulletin, Table 1.35.

\section{Long-term interest rates}

Belgium Public sector bonds with a remaining maturity of at least six years, issued to the public: market yield, Banque Nationale de Belgique, Monthly Report, Table XIX.6.

Canada Government of Canada bonds with a remaining maturity of over ten years, secondary market yield, Bank of Canada Review, Table F1.

France $\quad$ Long-term bond yield: secondary market yield on public and semi-public sector bonds. Loans subject to withholding tax. Bank of France Quarterly Bulletin, Statistical Supplement, Table 4.7.

Germany Federal public bonds with a remaining maturity of ten years, Deutsche Bundesbank Monthly Report, supplement series 2, Table II.7 (a missing value for June 1983 was filled in by straightline interpolation).

Japan Government bonds, market yield on ten-year, interest-bearing bonds, Bank of Japan, Economic Statistics Monthly, Table 67.

Netherlands Medium-term (five to eight-year) central government bonds, average market yield to maturity, De Nederlandsche Bank, Quarterly Bulletin, Table 9.2.

United Ten-year government stock yield, before tax, excluding index-linked and Kingdom variable rate issues, ones with provision for sinking fund, for redemption by drawings or for conversion into another stock. Bank of England Quarterly Bulletin, Table 7.3.

United US Treasury bond yield, ten-year constant maturity, Federal Reserve

States Bulletin, Table 1.35.

\section{Leading indicators}

United Composite of five longer leading indicators, Government Statistical Service, Kingdom Office for National Statistics, Economic Trends, Table A.

United Composite index of 11 leading indicators, Survey of Current Business, US

States Department of Commerce.

Other From the OECD's monthly publication, Main Economic Indicators, page 14. countries 


\section{References}

Artis, M.J., Z.G. Kontolemis and D.R. Osborn (1995): "Classical business cycles for G7 and European countries". CEPR discussion paper, 1137, March.

Bernanke, B.S. (1990): "On the predictive power of interest rates and interest rate spreads". New England Economic Review (Federal Reserve Bank of Boston), November/December, pp. 51-68. London, January.

Bomhoff, E. (1995): Financial Forecasting for Business and Economics, Academic Press,

Chen, N.-F. (1991): "Financial investment opportunities and the macroeconomy". Journal of Finance, 46 (2), June, pp. 529-54.

Estrella, A. (1995): "Measures of fit with dichotomous dependent variables: A critical review and a new proposal". Mimeo.

Estrella, A. and G.A. Hardouvelis (1991): "The term structure as a predictor of real economic activity". Journal of Finance, 46 (2), June, pp.555-76.

Estrella, A. and F. Mishkin (1995a): "Predicting U.S. recessions: Financial variables as leading indicators". Mimeo.

Estrella, A. and F. Mishkin (1995b): "The term structure of interest rates and its role in monetary policy for the European Central Bank". NBER working paper, 5279, September.

Fama, E.F. (1990): "Term-structure forecasts of interest rates, inflation and real returns". Journal of Monetary Economics, 25 (1), January, pp. 59-76.

Gerlach, S. (1995): "The information content of the term structure: Evidence for Germany." Forthcoming in Empirical Economics.

Hu, Z. (1993): "The yield curve and real activity". IMF Staff Papers, 40 (4), December, pp. 781-804.

Jorion, P. and F. Mishkin (1991): "A multicountry comparison of term-structure forecasts at long horizons”. Journal of Financial Economics, 29 (1), March, pp. 59-80.

Mishkin, F. (1990): "The information in the longer maturity term structure about future inflation”. Quarterly Journal of Economics, 105 (3), August, pp. 815-28.

Pindyck, R.S. and D.L. Rubinfeld (1991): Econometric models and economic forecasts, third edition. McGraw-Hill, New York.

Plosser, C.I. and K.G. Rouwenhorst (1994): "International term structures and real economic growth". Journal of Monetary Economics, 33 (1), February, pp. 133-55. 
No.

Title

Contagious speculative attacks

September 1994

23

October 1994

24

April 1995

25

April 1995

26

April 1995

27

May 1995

28

August 1995

29

September 1995

30

November 1995

31

December 1995

32

December 1995

33

January 1996

34

January 1996

35

July 1996

36

August 1996
The changing borders of banking: trends and implications

The structure of credit to the non-government sector and the transmission mechanism of monetary policy: a cross-country comparison

A survey of non-financial sector balance sheets in industrialised countries: implications for the monetary policy transmission mechanism

The monetary transmission mechanism:

evidence from the G-7 countries

The response of short-term bank lending rates to policy rates: a cross-country perspective

The term structure of Euro-rates: some evidence in support of the expectations hypothesis

The information content of the term structure: evidence for Germany

Money demand stability and currency substitution in six European countries (1980-1992)

Testing the quantity theory using long-run averaged cross-country data

The anatomy of the bond market turbulence of 1994

Derivatives and asset price volatility: a test using variance ratios

Monetary policy and the behaviour of interest rates: are long rates excessively volatile?

Varieties of monetary policy operating procedures: balancing monetary objectives with market efficiency

Estimation of speculative attack models: Mexico yet again
Author

Stefan Gerlach and Frank Smets

Claudio E.V.Borio and Renato Filosa

Claudio E.V. Borio

John T. Kneeshaw

Stefan Gerlach and Frank Smets

Claudio E.V. Borio and Wilhelm Fritz

Stefan Gerlach and Frank Smets

Stefan Gerlach

Renato Filosa

Stefan Gerlach

Claudio E.V. Borio Robert N. McCauley

Benjamin H. Cohen

Stefan Gerlach

Joseph Bisignano

William R. Melick 